\title{
Preservice Teachers and the Kairos Blanket Exercise: A Narrative Inquiry
}

\author{
Sandra Jack-Malik, Janet L. Kuhnke, and Kristin O'Rourke
}

\begin{abstract}
This narrative study inquired into the experiences of preservice teachers who participated in the Kairos Blanket Exercise. During research conversations, participants shared stories that demonstrated an expansion of their knowledge and awareness. Three themes emerged: the Blanket Exercise and the research conversations were spaces where participants felt safe to ask questions; some participants began to rewrite their understanding of the history of relations; and some participants began to consider how they might contribute to decolonizing. Moreover, participants enriched by the experience were more ready and able to deliver related curricular outcomes, engage reflexively, and consider allyship.
\end{abstract}

\section{Background}

The Department of Education at Cape Breton University (CBU, 2018) has as part of its mission and core focus to "prepare teachers, who will be knowledgeable, skillful, flexible, research-minded, culturally responsive, caring pedagogues" (p. 1). As part of their efforts to meet this focus, the department created a professional development series for its preservice teachers: the Pre-practicum Professionalism Series (O'Rourke, 2017). The series, now a tenet of the CBU's Bachelor of Education (BEd), was designed to complement and enrich the experiences of preservice teachers. Guided by Nova Scotia's Action Plan for Education (2015), which states Treaty Education must be part of the grade primary to 12 curriculum, and the Truth and Reconciliation Commission Calls to Action (TRC, 2015), the Kairos, Blanket Exercise (KBE) is part of the professionalism series. Participation in the KBE provides opportunities to develop, deepen, or shift understandings of the shared history of relations between settlers and Aboriginal people, ${ }^{1}$ while thinking about how said history continues to influence students, communities, teaching, and learning. It also affords participants opportunities to explore white privilege, "a built-in advantage, separate from one's level of income or effort" (Collins, 2018, para. 13).

\section{Description of the Kairos Blanket Exercise}

The Kairos Canada, Blanket Exercise, utilizes a participatory methodology. The goal is to build understanding about our shared history as Indigenous and non-Indigenous peoples in Canada by walking through pre-contact, treaty-making, colonization and resistance. Everyone is actively involved as they step onto blankets that represent the land, and into the role of First Nations, Inuit and later Métis peoples. By engaging on an emotional and intellectual level, the Blanket Exercise effectively educates and increases empathy. (Kairos Canada, 2020, para. 2) 
The Kairos, Blanket Exercise includes descriptions of historical and current-day events. Participants are invited to read aloud or listen as brief descriptions of the events are shared. This reading, listening, and responding provides opportunities for the participants to reflect on what they know and how they learned it. As participants move through the KBE experience, they are afforded opportunities to think about, and later, during the Talking Circle, discuss what they learned and what their learning means to them as individuals and soon-to-be teachers. Somers (1994) helped us to understand this process when she wrote, "all of us come to be who we are by being located or locating ourselves in social narratives" (p. 606). The KBE supports preservice teachers as they work to understand who they are and who they might become within reconciliation narratives and soon to be teachers, charged with delivering Treaty related educational outcomes.

On the day of the $\mathrm{KBE}$, the facilitation team arrives early to thoughtfully engage in creating a physical space (See Figure 1) that supports the text and evokes responses, while also being safe. Because we have worked together on numerous KBEs, we understand participants' reactions and comments, while normal, can be wide ranging and impactful. We appreciate our quiet conversations as preparation and as time to shore ourselves up as individuals, and as a team to be fully present in our efforts to facilitate the creation of a safe and caring space.

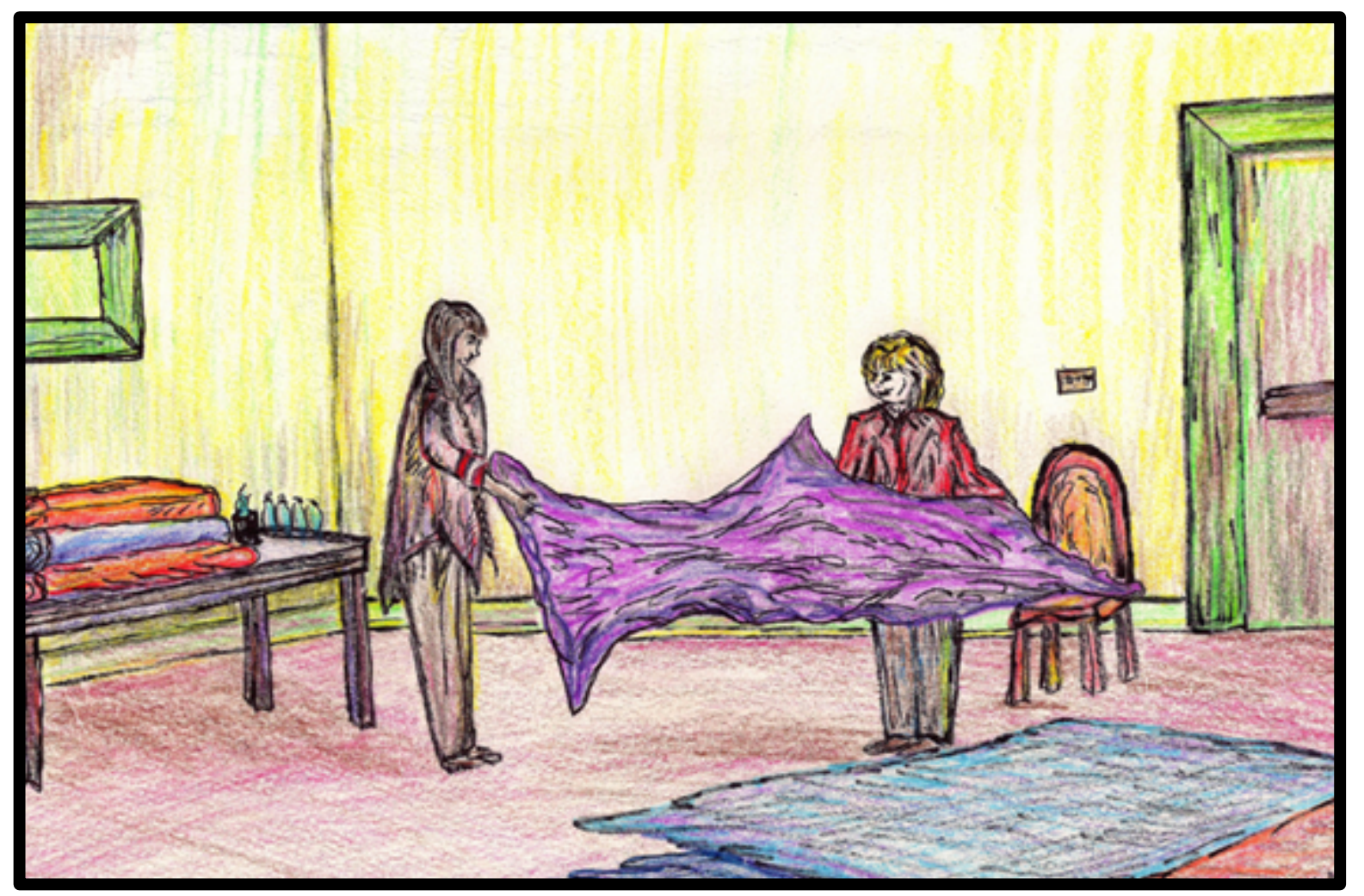

Fig. 1: Together we place coloured blankets on the floor. We do this slowly and reverentially, knowing they represent northern Turtle Island (present-day Canada). The facilitation team is led by Aboriginal colleagues and supported by settler allies (Regan, 2010). 
Participants remove their shoes, step on the blankets, and enter the dynamic precontact world of Aboriginal People. They are handed cards, scrolls, and artifacts and invited to "perform" the experiences of Aboriginal mothers, fathers, or family members. The performance is purposeful in that it "draws our attention to what matters" (Fels, 2011, p. 340). The narrator commences by describing events endured by Aboriginal People at the hands of colonizers. Some of these events include loss of land, children being forced to attend Indian Residential Schools, forced relocations, loss of language, culture, family, and economies. Some of which results in death. When a death occurs, participants are directed to step off Turtle Island. As the exercise continues, the land inhabited by Aboriginal people shrinks dramatically, as does the population. Interwoven throughout the narratives of loss, the narrator shares stories describing efforts by Aboriginal people to interrupt the ravages of colonization.

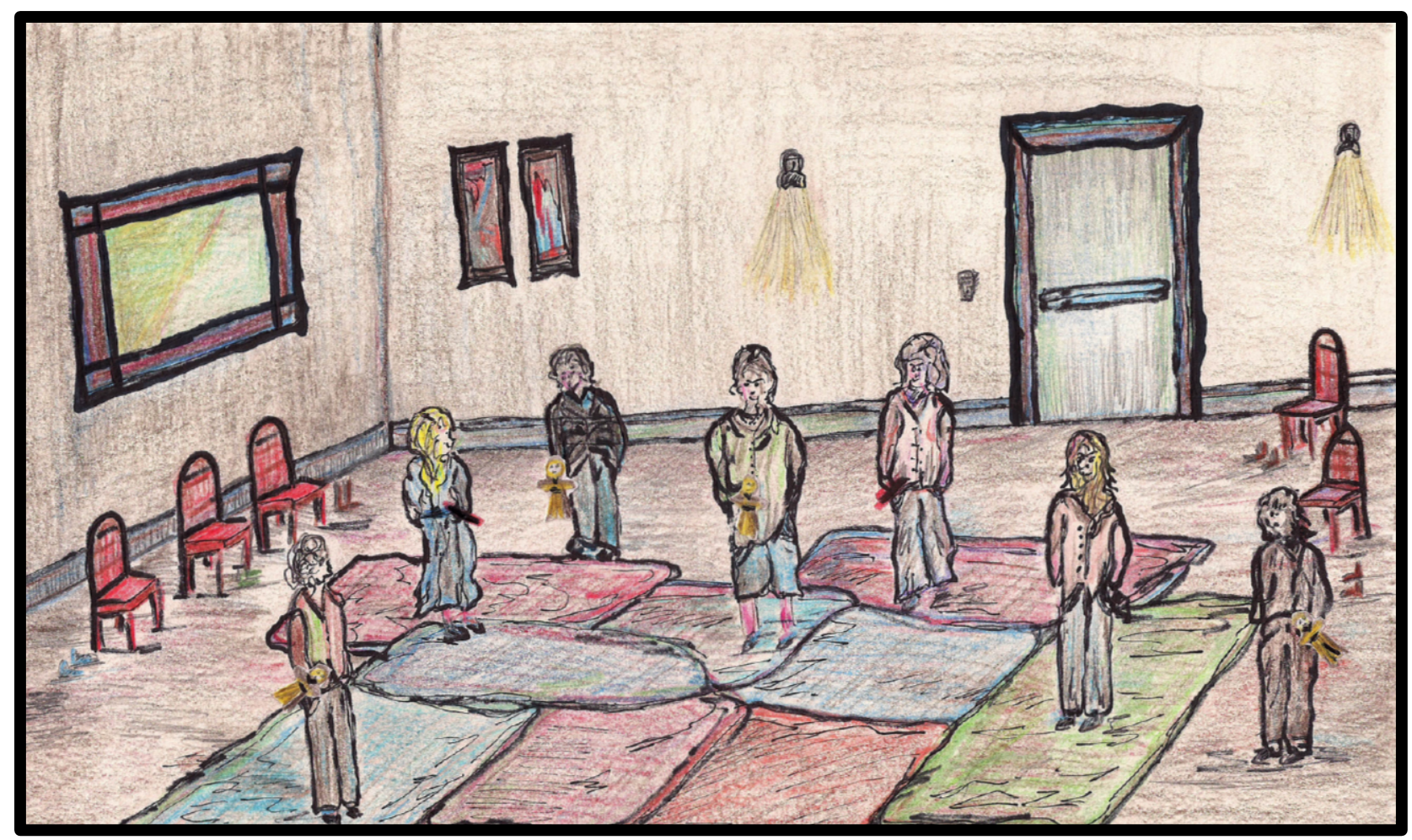

Fig. 2: Participants remove their shoes and step on the northern part of Turtle Island. Facilitators distribute handmade dolls representing the children who were forcibly removed from their homes and sent to Indian Residential Schools and/or children who died from disease. Some participants hold numbered scrolls, which they are invited to read when the number is called. The scrolls contain information about the history of the relations.

At the completion of this section of the $\mathrm{KBE}$, participants are directed to recall Turtle Island and the number of people who were on the blankets at the beginning of the exercise. They are asked to hold the image in their mind as they look at the dramatically decreased and non-connected landmass, which is represented by reserves, tracts of land set apart for Aboriginal People (See Figure 2). After moments of quiet reflection, participants are invited to join a Talking Circle led by the Elder in Residence who introduces and explains the tradition of a Talking Circle. ${ }^{2}$ As well, he graciously shares his story. The Talking Stick is then passed around and each participant is afforded the opportunity to share. 


\section{Why the Kairos Blanket Exercise}

Understanding and acknowledging the shared history contained within the KBE provides preservice teachers opportunities to "challenge racial constructs and boundaries [and] face challenges in a society in which racial categories have profound meaning" (Diangelo, 2018, p. xvi). Moreover, Taiaiake (2010) argues, "non-Natives must struggle to confront their own colonial mentality, moral indifference, and historical ignorance as part of a massive truth telling about Canada's past and present relationship with the original inhabitants of this land" (as cited in Regan, 2010, p. x). As educators of preservice teachers, it is our responsibility to include opportunities for students to explore and reflect on their beliefs, deepen their understanding of our shared history while preparing to teach it.

\section{Theoretical Underpinnings}

We were interested in understanding the experiences, the stories to live by of preservice teachers before and after they participated in the KBE. We were interested in their stories because we understand, "if we change the stories we live by, quite possibly we change our lives" (Okri, 1977, as cited in King, 2003, p. 153). Connelly and Clandinin (1990) used the term "stories to live by," as a narrative term for identity. Clandinin (2013) wrote stories to live by, "allows us to speak of the stories that each of us lives out and tells of who we are, and are becoming" (p. 52). We inquired into stories because "narratives are the form of representation that describes human experience as it unfolds through time" (Clandinin \& Rosiek, 2007, p. 40). We held this notion in our minds as we thought deeply about the stories and the wonders preservice teachers shared. Dewey's (1981) notion of experience guided us: "things and events belonging to the world, physical and social, are transformed through the human context they enter, while the live creature is changed and developed through its intercourse with things previously lived" (pp. 256-257). Moreover, Dewey's (1938) notion of continuity of experience informed the work. It helped us understand how early familial ${ }^{3}$ and school curriculum-making ${ }^{4}$ stories were shaping influences on who participants were, and who they imagined they might become (Greene, 1977). Another Deweyan (1938) notion that informed this work was the idea that an experience is educative or mis-educative; it helped distinguish between experiences "that have the effect of arresting or distorting the growth of further experience" (p. 25), and those that supported the preservice teachers as they worked to shift their stories to live by, expanding their knowledge of our shared history.

\section{Methodological Framework}

Narrative inquiry (Clandinin \& Connelly, 2000) is a relational, recursive, reflexive, and qualitative research methodology and a way to understand experiences narratively. It is grounded in the view that humans individually and socially live storied lives (Clandinin, 2013). "To use narrative inquiry methodology is to adopt a particular view of experience as phenomena under study" (Connelly \& Clandinin, 2006, p. 375). The stories of preservice teachers before and after they experienced the KBE was the phenomena under study. 
Leaning into Huber and colleagues' (2013) notion of narrative inquiry as pedagogy, Jack-Malik and Kuhnke (2020) pushed their thinking to include narrative inquiry as andragogy, the art and science of helping adults to learn (Mews, 2020). This was purposeful because much of what happens in classrooms is focused on pedagogies to support students to achieve learning objectives, leaving little time for teachers to participate in and learn from reflexivity activities related to their own practices (Finlay, 2012, 2017). Naming narrative inquiry as andragogy, the authors were purposeful in their intention for the research methodology to include opportunities for participants to engage in reflexivity, and thereby encourage them to understand the importance and value of continuously knowing themselves as learners, and subsequently making time for inquiry and self-reflection into their learning. Decolonization, including efforts to create counterstories to existing, often hegemonic institutional narratives, are complex processes. Lindemann Nelson (2001) described counterstories as "narrative(s) that take up a shared but oppressive understanding of who someone is, and set out to shift it" (p. 95). The methodological framework therefore was carefully and purposefully selected to allow participants to deeply engage with the subject matter, while also allowing opportunities to reflect on who they are as preservice teachers and who they might become.

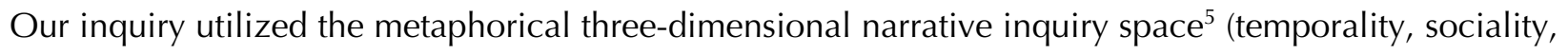
and place), allowing us to think through the three-dimensional space to understand the experiences of the participants. Four preservice teachers, Justin, Mitt, Rick, and Marg, ${ }^{6}$ were invited to participate in research conversations, six months after they participated in the KBE and having just completed their 16-week practicum experience. During the research conversations, they shared stories, including those from early school and familial curriculum-making experiences (Murphy et al., 2012). We attended to the temporality of the stories, when they took place, the contexts in which they occurred, the sociality, and physically where they took place. Specifically, we inquired to understand how the stories were shaping participants' understanding of the history of relations between Aboriginal and non-Aboriginal people and their privileges. Stories included tensions, which became places of inquiry (Clandinin, 2013). Tensions occurred during practicum, while reflecting on early home and school curriculum making, or when attempting to compose future-looking stories of who they were becoming as they moved from preservice to practicing teachers.

\section{Conceptual Framework}

Connelly and Clandinin's (1988) notion of personal practical knowledge-the experiential, moral, emotional, embodied knowledge teachers hold and express-helped us understand the narratives that participants shared. Furthermore, their concept of "stories to live by" helped us understand how the stories reflected their identities as teachers in the making.

\section{The Importance of the Work}

This work is important because it inquired into stories, shared by preservice teachers about how their knowledge and awareness related to the shared history of relations between Aboriginal and non-Aboriginal 
people and was influenced by their participation in the KBE. It is also important because it investigated implications for teacher educators within the framework of the Calls to Action of the Truth and Reconciliation Commission (2015) and the Nova Scotia Teaching Standards (2018).

\section{Our Positioning}

The authors are tenure-track, assistant professors at CBU. They identify as settlers and allies (Regan, 2010), working to decolonize themselves, their practices, and the academy. Jack-Malik also identifies with her maternal $\mathrm{L}^{\prime} \mathrm{nu}^{7}$ relations. Working with an Elder in Residence and Aboriginal colleagues, Jack-Malik and Kuhnke help to facilitate the KBE. O'Rourke is the designer and course instructor of the Pre-Practicum Professionalism Series.

\section{Mitt ${ }^{8}$ Shares:}

I had not done the KBE before. I had heard of it, and I had heard of the Africville kit. And I know the Africville Kit has nothing to do with the history, the KBE explores; however, it has the same concept of getting kids physically seeing the changes. It touched me more than I thought it would because you physically got to see the blankets taken away and people getting pulled off the floor, which meant they died. And some people got tuberculosis. Seeing how at one time the Mi'kmaq people had this huge plot of land and then they were down to little crumpled up blankets, scattered around put it into perspective, how much trauma they went through. (Research conversation, May 2019)

\section{Inquiry Into Mitt's Story}

Fels' (2011) notion of performative inquiry is a way of "drawing our attention to what matters" (p. 340). What mattered to Mitt was making links to his preexisting knowledge of the Africville Kit (Africville Museum, 2020), an educational resource designed to increase awareness of 150 years of resistance and protest by African Nova Scotian families. His comments focused on the participatory nature of the two experiences and how they are good for kids. Moreover, he described tensions (Clandinin, 2013) as he "saw" Turtle Island shrink, and "saw" Aboriginal people dying from tuberculosis. ${ }^{9}$ Mitt's participation and observations allowed him to deepen his understanding of some of the historic trauma endured by Aboriginal people. Furthermore, thinking like a teacher, he made pedagogical connections between the experiences. He commented on the benefits for children; however, he stopped short of making connections to the ongoing, systemic racism, suffering, and injustices endured by Aboriginal peoples and the need for individual decolonization by settlers (Regan, 2010). Mitt did not make connections to self, nor did he use the opportunity to engage in decolonization of self. Rather he reflected on "safer" pedagogical concerns for future students. Richardson et al. (2017) helped us understand when they wrote:

The path to participation and accountability may be long, and in its early days, but it must continue in the post Truth and Reconciliation Canada. And while many learners are prepared, at various points, to take up a stance of "giving back" or living differently, not everyone is ready to make a social justice commitment. (p. 340) 
Moreover, Regan (2010) sheds additional insight when she wrote:

That settlers fail to see the importance of accepting responsibility for the IRS (Indian Residential Schools) ${ }^{10}$ is hardly surprising. Maintaining a comfortable intellectual, psychological and emotional distance from the harsh realities that the system engendered enables us to retain an identity as well-intentioned, humane citizens - benevolent peacemakers. (pp. 42-43)

Mitt made links; however, he did not use the KBE experience to interrogate his positioning and privilege as a white male. The question that lingers with us is: Can a settler educator teach the history of relations between settlers and Aboriginal people without having begun the process of interrogating their own privilege? Richardson and colleagues (2017) described the importance of work done by allies to interrupt ongoing narratives of racism:

The victims of racism are not responsible for stopping it; that is ally work where White folks from the dominant culture can help their brothers and sisters when they go off track. She asks us to "lean in", and not away, when one of our group members behaves badly, both including the person and challenging the person's unethical or dangerous behaviour. (p. 340)

How will Mitt be able to do this in his classroom if he has not begun to interrogate his beliefs and privileges? We don't think he can; however, we remain hopeful because of his willingness to participate in the KBE and the research conversations (voluntary activities). We also understand the importance of creating teaching and research spaces that are experienced as safe. We are therefore reluctant to describe Mitt's inability to draw himself into the decolonization process as a failure. We understand if we are to continue to make progress, we must remain open to all openings, not only those we label as the most educative (Dewey, 1938). Mitt engaged with us, shared his thinking, made links to his developing pedagogies; these are steps forward on his path to decolonizing.

\section{Justin Shares:}

I am the height of privilege being a white, native English-speaking male. I was the third person exiled off of ' $m y$ ' blanket during the KBE and that was a feeling I have never felt before. We talk about the importance of differentiating between one's privileges (whiteness, male, native English speaker) and one's personal story (my mental health issues). In a social, public environment, being exiled was something I had never experienced. I felt the exclusion in personal ways. In terms of being in a group of people and then all of a sudden, being told to 'book it', that is something that has never happened to me. However, if I were black, it wouldn't have even had an impact on me, maybe. My reaction was a very powerful feeling and I thought 'oh my gosh, this is crazy that I'm being excluded in the KBE!' I also had a physiological thing that happened in my throat when I was exiled. In other situations, I have felt excluded in personal ways because of my mental health. I don't know if that's an appropriate link. I think it's different but I think empathy can come from that. I am not trying to equate experiences of Mi'kmaq people with my mental health; however, it has helped me see through a more empathetic lens. (Research conversation, May 2019) 


\section{Inquiring Into Justin's Story}

Justin begins by stating his privileges (Kendall, 2002) and positioning. However, the moment he was directed to step off Turtle Island resulted in what Applebaum (1995) described as a "stop" —a moment when his privileges came into tension (Clandinin, 2013) with the role he was enacting. Justin did not appreciate this. He had a physiological reaction. Regan (2010) states:

Viewed in this way, settlers' questions, especially the difficult ones that spring to mind as we listen and that we might try to suppress, are precisely those that most urgently need our attention. Settler response to Indigenous testimonies, our questioning, may reveal themselves not only, or even primarily on an intellectual level, but in the feelings and physical reactions that such testimonies engender. (p. 190)

Justin struggled to temporarily perform the role of an Aboriginal person. His reactions were grounded in tensions that resulted when his privileged positioning came into conflict with the racist, exclusionary experiences endured by the Aboriginal person he was asked to enact as part of his participation in the KBE.

The inquiry that follows is complex and dichotomous. Justin stated a Black participant of the KBE would not have been affected by being asked to step off. This indicates an awareness of hierarchies related to skin colour. As well, it speaks to messages he internalized about the lives of racialized individuals. Justin is able to name racialization as hierarchical; however, he does not connect his whiteness and unearned privileges as part of the issue. Moreover, Justin's language choice was repeatedly harsh, including terms such as "exiled" and being told to "book it," when in fact the script reads, "will you please step off the blanket" (Kairos Canada, 2020, p. 3). As well, he names the blanket "my blanket," suggesting ownership of the blanket and the land it represents. Justin's comments have us asking questions about the messages he inculcated and internalized about racialized people and their lived experiences, alongside messages of white superiority, resulting in unearned privileges.

As educators inquiring into Justin's research conversations, we experienced a stop (Applebaum, 1995). We reflected in dialogue, quietness, and with the research literature. We felt ourselves engaging in dangerous conversations ${ }^{11}$ (Le Fevre \& Sawyer, 2012). Applebaum (1995) helped us to frame our stop and our conversations when he stated:

The stop hides in a most hidden place. This is a place that is both near and obvious. As if being of the same polarity, our habits impel the gaze toward what is distant and complicated. To gaze is in fact to look far off, toward the unapproachable, the not-at-hand. It is a look of dis-satisfaction, peering behind, around, in back of, rather than directly at what is in front. It is an averted look. The habit is of ignoring the call of the personal, cultural, and human...That what lurks might hold up a mirror to the self and its fears and desires is a repugnant possibility. (p. 16)

Greene (1995) described this as seeing big and seeing small. ${ }^{12}$ We understand from Justin's position of power-possible because of his privileges-he was able to see small, from a distance. He was not however able to see big-close up, personal, from the lived experiences of the Aboriginal person he was invited to perform. In some ways we felt implicated by his comments, as if we failed to support him to 
interrogate his privileges. Diangelo (2018) guided our thinking when she wrote, "racism is so deeply woven into the fabric of our society that I do not see myself escaping from the continuum in my lifetime however [as educators, we want to be] actively seeking to interrupt racism" (p. 87).

When Justin spoke, we did not follow up with questions about his comment as to how a Black participant would have experienced being asked to step off Turtle Island. We did not name this a racist comment, nor did we support him to engage in self-awareness (Greene, 1995). We now understand this as a missed opportunity to support his decolonizing journey. We also understand this as a moment of tension between self as educator and researcher (Clandinin, 2013). Moreover, we understand this as part of our privileged positioning (Regan, 2010).

Justin was able to describe his uniqueness as one who lives with mental health issues. He described his ability to connect this uniqueness through empathy to the lives of people marginalized. He was also able to name the unearned privileges he enjoys. However, he was not able to suspend his unique self-perception to see the wider impacts of societal racism and the suffering endured by marginalized individuals and communities, and how he is implicated as a member of the white people group.

\section{Marg Shares:}

I enjoyed the opportunity to reflect on my KBE experience during the Talking Circle and while holding the Talking Stick. It was interesting to hear the comments from my classmates as we passed the Talking Stick around. Everyone's comments and reflections helped me in my own process of taking in knowledge and reflecting on the KBE. The Talking Circle experience allowed me to take time to concentrate, reflect, and learn from others' perspectives of the KBE experience.

It has been over 10 years since I graduated from high school. We definitely learned about different things that happened to Aboriginal people in Canada and there was a timeline set up, but the KBE was more extensive and different from what I was taught in high school. History was definitely not presented so that we understood traumatic colonization is ongoing, still happening today.

I have always tried to be aware of who my students are, what traditions are celebrated and to what extent, because it varies from family to family and from school to school. I think I will bring my awareness of Aboriginal histories to my classroom. I will ask what are the traditions in this country, or, what are the different family backgrounds represented in my classroom. (Research conversation, May 2019)

\section{Inquiring Into Marg's Story}

Marg speaks about the value she experienced as part of the Talking Circle. Mehl-Madrona and Mainguy (2014) describe the Talking Circle as follows:

A Talking Stick is held by the person who speaks... When that person is finished speaking, the Talking Stick is passed to the left...Only the person holding the stick may speak. All others remain quiet. The circle is complete when the stick passes around the circle one complete time without anyone speaking out of turn. The Talking Circle prevents reactive communication and directly responsive communication, and it fosters deeper listening and reflection in conversation. (p. 4) 
We understand participation in the Talking Circle as performative inquiry (Fels, 1998). The performance allows time to explore, reflect, and learn; to develop knowledge of the history of relations between settlers and Aboriginal people. The listening and reflecting time allowed Marg to rewrite her knowledge of the trauma endured by Aboriginal people. Specifically, she shifted what she knew as historical events to a knowing that trauma and systemic racism are not things of the past. She came to understand that Aboriginal people continue to experience trauma, exclusion, and suffering (Regan, 2010).

Marg previously worked as a teacher at an international school. We were not surprised therefore when she applied what she learned from the KBE experience and "imagined up," how she would implement her learning in an international classroom. Greene (1995) helped us to frame Marg's imagining when she, leaning into Dewey's (1981) work, wrote:

When it came to the meeting of past experiences with present ones... [Dewey] emphasized the ways in which the formed matter of an aesthetic experience (Marg's KBE and Talking Circle performances) could directly express meanings also evoked when imagination begins to work. (p. 76)

Marg's imaginings allowed her to describe a desire to pay more attention to children and their families. Specifically, she talked about acknowledging and including individual customs and traditions.

We understand her imaginings through three lenses. First, the performative inquiry of the Talking Circle and KBE allowed Marg to rewrite her understanding of relations between settlers and Aboriginal people. Next, she began to imagine up what her new understanding would look like pedagogically in an elementary international classroom. And finally, she imagined one further step in that she described a desire to be more informed about the cultures and traditions of her future students and their families (Lemaire, 2020). Greene (1995) stated, "the role of imagination is not to resolve, not to point the way, not to improve. It is to awaken, to disclose the ordinarily unseen, unheard, and unexpected" (p. 28). We understand these three steps as Marg's awakening, moving from seeing small, to seeing big (Greene, 1995). And as her focus shifted from seeing small to big, the potential for her to come alongside $^{13}$ the children in meaningful and educative ways also grew (Dewey, 1938).

\section{Discussion: Interrupting Privileged Narratives is Possible}

Regan (2010) helped us understand the shaping influence of the KBE and the stories participants shared during the Talking Circle and the research conversations when she wrote: "under what circumstances would those who are beneficiaries of colonialism stop denying and choose to act differently" (p. 66). Holding this wonder, we began to understand the KBE as one tool to nudge participants towards calling out unearned privileges, and acknowledging a history of relations that accurately reflects what occurred. Moreover, participants' performance (Fels, 2011) during the KBE, their engagement with the Talking Circle, and the research conversations, created andragogical spaces where they felt safe to engage complex subject matter and have difficult conversations (Le Fevre \& Sawyer, 2012). They described privileges they enjoy based on "their whiteness." Participants "question[ed] colonialism as an ongoing system that establishes unfair and wide-spread domination and privileges" (Lemaire, 2020, p. 308). 
Diangelo (2018) helped us to understand how white appearing regularly results in an individual benefiting from ongoing colonialism, including experiencing unearned privileges. The KBE and we would argue narrative inquiry as andragogy, creating circumstances where participants, through self-reflection, questioning, discussion, and performance, were, as Regan (2010) suggested, able to shift narratives of denial and unawareness. They experienced a stop (Applebaum, 1995). Fels (2011) described the experience of a stop as follows:

... a moment of risk, a moment of opportunity. Applebaum's stop moments are those moments that interrupt, that evoke new questioning, that make visible our habits of engagement, our biases, issues we have overlooked or have never considered. It is through our questioning and reflection of these stop moments that new learning becomes possible. Such moments of recognition are those moments when we see a situation or issue from a new perspective, and while we may or may not embody this new learning within the role drama, it may influence us in future interactions. A stop is a moment that calls us to attention; a moment of recognition when we realize that there are other possible choices of action, other ways of being in engagement. (p. 341)

Having experienced a stop, participants were then able to, as Laenui (2000) described, engage in imagining up future educative (Dewey, 1938) stories that include a time when "the full panorama of possibilities is expressed, considered through debate, consultation, and building dreams on further dreams which eventually become the flooring for the creation of a new social order" (Laenui, 2000, p. 155). For preservice teachers then, their participation in the KBE was educative (Dewey, 1938), in that they engaged in imagining future stories that include Aboriginal perspectives, while engaging in more meaningful relationships with Aboriginal students, colleagues, communities, and nations.

\section{Conclusion}

Narrative inquiry as a research methodology resulted in andragogical spaces (Jack-Malik \& Kuhnke, 2020) where participants felt safe to listen, ask questions, trouble their understandings, and share their stories related to the history of relations between Aboriginal and non-Aboriginal people. Within these safe spaces they also began to imagine future stories reflecting an increase in confidence to deliver Treaty Education outcomes within classrooms where students feel included. This is important because, like Okri (1977, as cited in King, 2003), we understand changing our stories can result in changes to our lives and to the lives of our students. As we look backward on our individual decolonizing journeys, we understand the truth-telling content embedded with the KBE, the participatory engagement, the resulting feelings, and the hoped-for subsequent actions must be known as a single experience upon which educators can choose to scaffold future learning (Lemaire, 2020). The KBE must not be framed as a one-time professional development experience that results in teachers becoming decolonized allies. Regan (2010) reminds us, "without a truth telling in which we confront our own history and identity, and make visible how these colonial practices continue today, there can be no ethical or just reconciliation with Indigenous peoples" (p. 235). Moreover, it is therefore important to learn more about other teaching and learning activities that help preservice teachers and teachers to continuously learn about the shared history, while becoming and nurturing allyship. Finally, if the intention is indeed to train preservice teachers to become allies, 
then provincial teacher competencies must include statements to this effect. Currently, Nova Scotia Teaching Standards (2018) do not include a single reference to Treaty Education. This "story" will have to change if we want to nurture decolonization (TRC, 2015; Call to Action 44) and reconciliation stories (TRC, 2015; Call to Action 53 iii), while building strong and enduring allyship (Battiste, 2013).

\section{Notes}

1. In this paper we lean into the nomenclature suggested by Battiste (2013) when she wrote: "I try to use [the word] Indigenous when considering the people beyond Canadian borders and use Aboriginal or First Nations, Metis, or Inuit for students in First Nations programs in universities" (pp. 13-14). We therefore make use of the word "Aboriginal" when referring to people who inhabited what is now referred to as Canada, prior to colonization. Content Warning: decolonization.

2. Elder Lawrence Wells leads by example, and is always ready to participate in activities with children and youth that incorporate the sacred in everyday life. He is a noted wood and stone carver and has crafted pipes for prayer. Lawrence is perhaps best known for his positive attitude, his generosity with his time, his knowledge of the Seven Sacred Teachings and ways we can heal ourselves, and for his affinity for nature. He does not believe in barriers and is available to students for support as needed (Unama'ki College. CBU, 2021). "Elders are recognized because they have earned the respect of their community through wisdom, harmony and balance of their actions in their teachings" (Indigenous Elder Training, 2020, para. 1). (Indigenous Corporate Training, 2020, para. 1). https://www.ictinc.ca/blog/indigenous-elder-definition.

3. Familial curriculum making is the curriculum making in which children engage with members of their families and communities (Clandinin et al., 2012, p. 9).

4. School curriculum-making is the places where the lives of children, families and teachers intersect and overlap (Clandinin, 2013).

5. Narrative inquirers and participants are situated within a "three-dimensional space with temporality, sociality, and place" serving as the three dimensions...thinking narratively means thinking through the three-dimensional space to understand lived experience (Clandinin, 2013, p. 38).

6. Pseudonyms for the four preservice teachers who engaged in follow-up research conversations.

7. Augustine (2016), states L'nu are "people of the earth," Mother Earth, and so we call ourselves Ilnu (p. 21).

8. Participant direct quotes are edited for clarity. 
9. The occurrence of tuberculosis remains disproportionately high in First Nation, Inuit, and Metis peoples (Jetty, 2020). https://www.cps.ca/en/documents/position/tuberculosis-among-firstnations-inuit-and-metis-children-and-youth

10. Over "150,000 Indigenous children were removed and separated from their families and communities to attend Indian Residential Schools (IRS). While most of the 139 IRS ceased to operate by the mid-1970s, the last federally run school closed in the late 1990s. In May 2006, the IRS Settlement Agreement (SA) was approved by all parties to the Agreement. The implementation of the SA began in September 2007 with the aim of bringing a fair and lasting resolution to the legacy of the IRSs" (Government of Canada, 2019, para. 1). https://www.rcaanc-cirnac.gc.ca/eng/1100100015576/1571581687074

11. Le Fevre and Sawyer (2012), state: "We began by discussing the meaning of the concept of dangerous conversations: What did the topic mean to us, and how could we locate ourselves and our research questions in it?" (p. 262).

12. Greene (1995) wrote about seeing big. She argued that by seeing big, we refuse epistemologically to consider people as objects; rather we view them embodied in the particularities of their lives. From this standpoint, Greene believes we can see people in the midst of their living and if we are attentive listeners, we can be privy to their plans, initiatives, and the fears they face.

13. Alongside: our ontological commitments shape how we live in the world... and come alongside participants. These commitments include attending to "the lives, the experiences, of those with whom we live in relation. Our commitments...are to the lives of the people involved" (Clandinin et al., 2015, p. 23).

\section{References}

Africville Museum. (2020). Africville kit. https://africvillemuseum.org/education-resources/

Applebaum, D. (1995). The stop. State University of New York Press.

Augustine, S. (2016). The Mi'Kmaw creation story. In M. Battiste (Ed.) Visioning a Mi'kmaw humanities: Indigenizing the academy (pp. 18-27). Cape Breton University Press.

Battiste, M. (2013). Decolonizing education: Nourishing the learning spirit. Purich.

Brookfield, S. D. (2015). The skillful teacher. Jossey-Bass.

Cape Breton University. (2018). Bachelor of education standardized syllabus template (p. 1). [CBU Intranet].

Cape Breton University. (2021). Elders in residence: Lawrence Wells. https://www.cbu.ca/indigenous-

affairs/unamaki-college/elders-in-residence/

Clandinin D. J. (2013). Engaging in narrative inquiry. Routledge Taylor \& Francis Group. 
Clandinin, D. J., Caine, V., Estefan, A., Huber, J., Murphy, M. S., \& Steeves, P. (2015). Places of practice: Learning to think narratively. Narrative Works: Issues, Investigations, \& Interventions, 5(1), 22-39.

Clandinin, D. J., \& Connelly, F. M. (2000). Narrative inquiry: Experience and story in qualitative research. Jossey-Bass.

Clandinin, D. J., Lessard, S., \& Caine, V. (2012). Reverberations of narrative inquiry. How resonant echoes of an inquiry with early school leavers shaped further inquiries. Educacao, 36, 7-24. https://www.fpce.up.pt/ciie/revistaesc/ESC36/ESC36_D.Jean_Sean\&Vera.pdf

Clandinin, D. J., \& Rosiek, J. (2007). Mapping a landscape of narrative inquiry: Borderland spaces and tensions. In D. J. Clandinin (Ed.), Handbook of Narrative Inquiry: Mapping a Methodology (pp. 35-76). Sage.

Collins, C. (2018). What is white privilege, really? https://www.tolerance.org/magazine/fall-2018/whatis-white-privilege-really

Connelly, F. M., \& Clandinin, D. J. (1988). Teachers as curriculum planners: Narratives of experience. Teachers College Press.

Connelly, F. M., \& Clandinin, D. J. (1990). Stories of experience and narrative inquiry. Educational Researcher, 19(5), 2-14.

Connelly, F. M., \& Clandinin, D. J., (2006). Narrative inquiry. In Green, J., Camilli, G. and Elmore, P (Eds.), Handbook of complementary methods in education research (p. 375). Lawrence Erlbaum.

Dewey, J. (1938). Experience and education. Collier.

Dewey, J. (1981). The later works, 1925-1953, Volume 10. Art as experience. In J. A. Boydston (Ed.). The collected works of John Dewey. Southern Illinois University Press.

Diangelo, R. (2018). White fragility: Why it's so hard for white people to talk about racism. Beacon Press.

Fels, L. (1998). In the wind clothes dance on a line. Jet. (pp. 29-36).

Fels, L. (2011). A dead man's sweater. In S. Schonmann (Ed.)., Key concepts in theatre/drama education, (pp. 339-343). Sense Publishers.

http://performativeinquiry.ca/pdfs/FelsL2011ADeadMansSweaterPerformativelnquiryEmbodiedAndRecognized .pdf

Finlay, L. (2012). Five lenses for the reflexive interviewer. In J. Gubrium, J. Holstein, A. Marvasti, \& J. Marvasti (Eds.), Handbook of interview research. Sage Publications.

Finlay, L. (2017). Championing "reflexivities". Qualitative Psychology, 4(2), 120-125.

Government of Canada. (2019). Indian residential schools.

https://www.rcaanc-cirnac.gc.ca/eng/1100100015576/1571581687074 
Greene, M. (1977). Toward wide-awakeness: An argument for the arts and humanities in education. Issues in Focus, 79(1), 119-125.

Greene, M. (1995). Releasing the imagination. Jossey-Bass.

Huber, J., Caine, V., Huber, M., \& Steeves, P. (2013). Narrative inquiry as pedagogy in education: The extraordinary potential of living, telling, retelling, and reliving stories of experience. Review of Research in Education, 37, 212-242.

Indigenous Corporate Training, Inc. (2021). Indigenous Elder definition.

https://www.ictinc.ca/blog/indigenous-elder-definition

Jack-Malik, S., \& Kuhnke, J. L. (2020). Narrative inquiry as relational research methodology and andragogy: Adult literacy, identities and identity shifting. Language \& Literacy, 22(2), 43-63.

Jetty, R. (2020). Tuberculosis among First Nations, Inuit and Metis children and youth in Canada: Beyond medical management. https://www.cps.ca/en/documents/position/tuberculosis-among-first-nationsinuit-and-metis-children-and-youth

Kairos Canada. (2020). The blanket exercise. https://www.kairoscanada.org/what-we-do/indigenousrights/blanket-exercise

Kendall, F. E. (2002). Understanding white privilege. CPT, pp. 1-11.

https://www.cpt.org/files/Undoing\%20Racism\%20-\%20Understanding\%20White\%20Privilege\%20$\%$ 20Kendall.pdf

King, T. (2003). The truth about stories: A narrative inquiry. House of Anansi Press.

Laenui, P. (2000). Process of decolonization. In M. Battiste (Ed.), Reclaiming Indigenous voice and vision (pp. 150-159). UBC Press.

Le Fevre, D. M., \& Sawyer, R. D. (2012). Dangerous conversations: Understanding the space between silence and communication. In. J. Norris, R. D. Sawyer, \& D. Lund (Eds.), Duoethnography (pp. 261-287). Left Coast Press, Inc.

Lemaire, E. (2020). Engaging preservice students in decolonizing education through the blanket exercise. Language and Intercultural Communication, 20(4), 300-311.

https://doi:10.1080/14708477.2020.1756837

Lindemann Nelson, H. (2001). Damaged identities, narrative repair. Cornell University Press.

Mehl-Madrona, L., \& Mainguy, B. (2014). Introducing healing circles and talking circles into primary care. The Permanente Journal, 18(2), 4-9.

Mews, J. (2020). Leading through andragogy. College and University, 95(1), 65-68.

Murphy, S.M., Huber, J., \& Clandinin, D. J. (2012). Narrative inquiry into worlds of curriculum making. LEARNing Landscapes, 5(2), 219-235.

Nova Scotia. (2015). Nova Scotia's action plan for education 2015: The 3 Rs: Renew, Refocus, Rebuild. (pp. 1-47). 
Nova Scotia. (2018). Nova Scotia teaching standards excellence in teaching and learning. (pp. 1-20). https://srce.ca/sites/default/files//Nova\%20Scotia\%20Teaching\%20Standards-

Comprehensive\%20Guide-2018.pdf

O'Rourke, K. (2017). Pre-professional development series. [CBU Intranet].

Regan, P. (2010). Unsettling the settler within. UBC Press.

Richardson, C., Carriere, J., \& Boldo, V. (2017). Invitations to dignity and well-being: Cultural safety through Indigenous pedagogy, witnessing and giving back! AlterNative, 13(3), 190-195.

https://doi.org/10.1177/117718011771

Somers, M. R. (1994). The narrative constitution of identity: A relational and network approach.

Theory and Society, 23(5), 605-649

Truth and Reconciliation Commission of Canada. (2015). Calls to action.

http://trc.ca/assets/pdf/Calls_to_Action_English2.pdf 


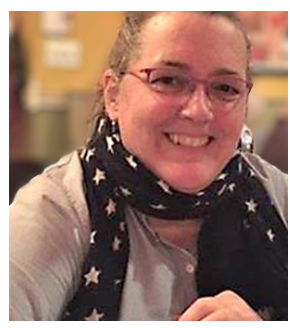

Sandra Jack-Malik is an Assistant Professor in the Department of Education at Cape Breton University. She is also chair of the Department of Education. Sandra teaches and learns from pre-service, Bachelor of Education students in the field of English Language Arts. She also teaches and learns from in-service teachers in the area of curriculum studies through an asynchronous online platform. Sandra researches: dyslexia, familial and school curriculum making experiences and reflexivity as a generative practice to sustain a career.

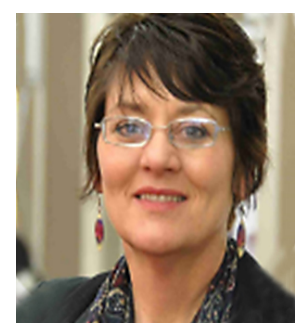

Janet L. Kuhnke is an Assistant Professor within the Department of Nursing at Cape Breton University with a strong background in community practice. Her recent research includes qualitative studies related to community members living with diabetes mellitus and being at risk for lower leg ulcerations and amputations. Janet also researches systemic, colonized barriers that exist within higher education. Janet is a reflexive practitioner who utilizes reflective activities and arts-based inquiry to inform her practice.

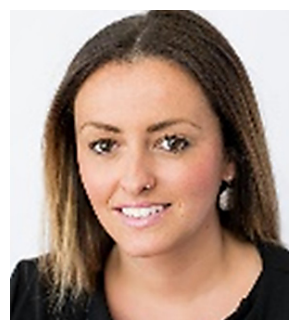

Kristin O'Rourke is an Assistant Professor in the Department of Education at Cape Breton University. Her research focuses on International Education contexts with an emphasis on internationalization of policy in higher education and internationalizing curriculum. She currently teaches Bachelor of Education methodology courses in Social Studies and French, and developed and teaches the pre-practicum professionalism series. 